\title{
Nerve conduction and electromyography in rheumatoid arthritis patients: a case - control study
}

\author{
Mohammed E. Sulaiman*, Shakir M. Sulaiman*, Hakki M. Majdal** \\ * Department of Physiology, College of Medicine, University of Mosul; \\ ** Department of Neurology, Ibn-Sina Teaching Hospital, Mosul.
}

(Ann. Coll. Med. Mosul 2012; 38 (2): 44-51).

Received: 20 ${ }^{\text {th }}$ Dec. 2010; Accepted: $25^{\text {th }}$ Dec. 2011.

\begin{abstract}
Objectives: This study aims to assess peripheral nerve conduction and electromyographic function abnormalities in patients with rheumatoid arthritis.

Subjects and methods: One hundred normal subjects and rheumatoid arthritis patients for each were included in this study, the normal subjects were matched regarding the age and sex with rheumatoid arthritis patients, rheumatoid arthritis patients were diagnosed according to American revised criteria (ARC) 1987; at the Department of Rheumatology in Ibn-Sina Teaching Hospital in Mosul city during the period of $15^{\text {th }}$ of November $2009-15^{\text {th }}$ of May 2010. Nerve conduction study for median, ulnar, radial (motor and sensory), posterior tibial and common peroneal nerves were done for all normal subjects and rheumatoid arthritis patients by using system 98-MyoQuik (micromed) EMG. Electromyography for tibialis anterior, gastrocnemius and quadriceps muscles were done for normal subjects and rheumatoid arthritis patients by using Dantec- Neuromatic 2000M-EMG.
\end{abstract}

Results: In this study, peripheral neuropathy was detected in 54 patients (54\%); mononeuritis simplex was the commonest lesion and detected in 36 patients $(66.6 \%)$ out of the 54 patients. The entrapment neuropathy was found in 25 patients $(46.74 \%)$, affecting the median $(24.07 \%)$, posterior tibial $(14.81 \%)$ and ulnar $(7.40 \%)$ nerves. Mononeuritis multiplex was detected in 11 patients $(20.37 \%)$, and symmetrical polyneuropathy found in 7 patients (12.90\%).

In the present study, the axonopathy (due to vasculitis mainly), and local demylination (due to entrapment mainly), were the common types of nerve injury seen in rheumatoid arthritis patients. Muscle involvement could be detected by electromyography in rheumatoid arthritis patients in this study.

Conclusion: Neurogenic lesions were present, while no myogenic lesion was detected in patients with rheumatoid arthritis.

Keywords: Electromyography, nerve conduction study, rheumatoid arthritis, nerve.

الخلاصة

الهـف: دراسة توصيل الأعصاب وتخطيط العضلات عند المرضى المصابين بالروماتزم الرثوي.

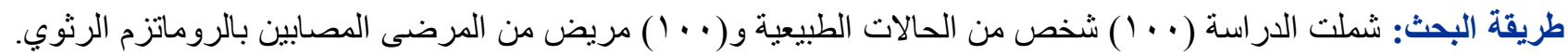

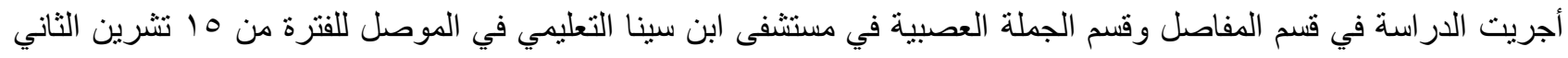

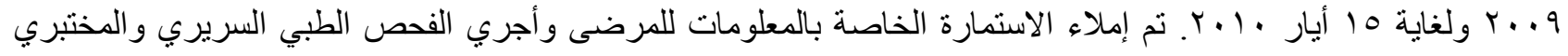

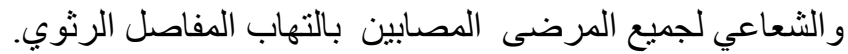

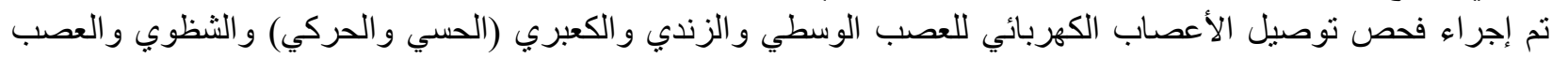

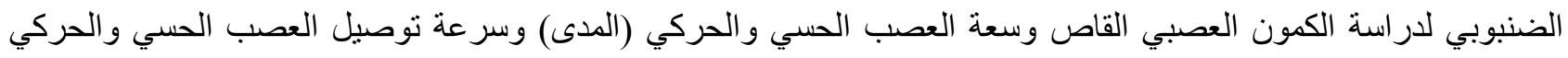
باستخدام جهاز: System 98-MyoQuick (micro med) EMG 
تم إجراء فحص تخطيط العضلات الكهربائي للعضلة الرباعية الفخذية والعضلة الضنبوبية الأمامية وعضلة الساق لدراسة

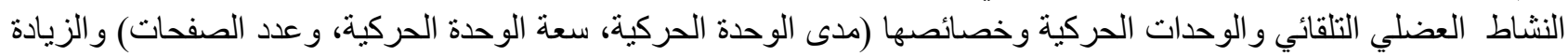

التدريجية في شدة انقباض العضلة باستخدام جهاز Dantec - Neuromatic 2000 EMG system.

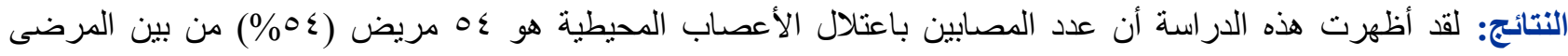

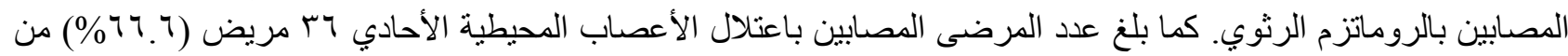

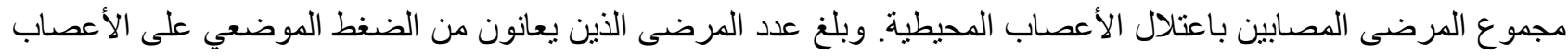

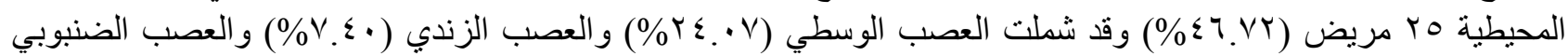

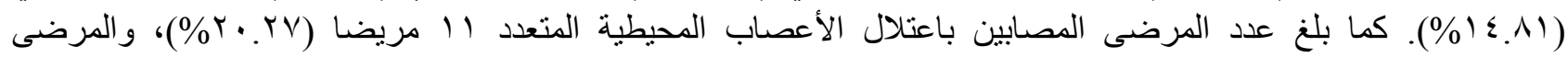

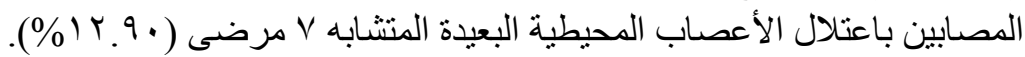

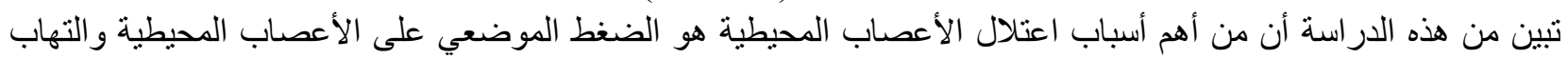
الأوعية الدموية التي تغذي الأعصاب المحيطية، و اللذان يؤديان إلى تحلل الغشاء الخارجي المحيط بالألياف العصبية و الى الى اعتلال مركز الألياف العصبية.

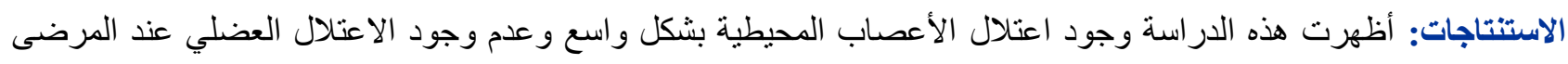
المصابين بالروماتزم الرثوي.

$\mathrm{R}$ heumatoid arthritis (RA) is associated with various neurological extra-articular manifestations including nerve compression by synovial proliferation, sensory or sensorimotor neuropathies, ${ }^{(1)}$ and impingent on the central nervous system (CNS) causing neurologic symptoms. ${ }^{(2)}$ Carpal tunnel syndrome is the most common compressive neuropathy in RA, Less common are tarsal tunnel syndrome and ulnar nerve entrapment. ${ }^{(3)}$

Mononeuritis multiplex is a form of combined sensorimotor neuropathy caused by vasculitis of epineural and perineural arteries and can present as acute foot or wrist drop, such patients usually have severe longstanding RA with other extra-articular features. ${ }^{(4)}$

Myopathy in RA is usually due to disuse atrophy, corticosteroid therapy, or both. Clinically significant disease-related myositis is very rare. ${ }^{(5)}$ Denervation atrophy from peripheral neuropathy is another cause of muscle weakness. ${ }^{(6)}$

Electromyography (EMG) and nerve conduction studies (NCS) typically comprise the electrodiagnostic evaluation of function of motor neurons, nerve roots, peripheral nerves, neuromuscular junction and the skeletal muscles. ${ }^{(7)}$ EMG/NCS are considered medically necessary for diagnosing the following conditions: Unexplained peripheral neuropathy with pain of a neuropathic pattern, demonstrated sensory or motor loss on physical examination and no known etiology,
Neuropathy suspected to be due to trauma, Carpal tunnel syndrome, ulnar neuropathy at the elbow or wrist, tarsal tunnel syndrome, Peroneal palsy with foot drop, cervical and lumbar radiculopathy. ${ }^{(8-11)}$

In EMG: Electrical potentials are detected by a needle electrode inserted directly into a skeletal muscle. It assists in clinical diagnosis, prognosis and clinical management decisions. ${ }^{(8)}$ It is helpful in distinguishing between inflammatory and chronic, metabolic or inherited muscle diseases; also in differentiating between acute, recovering and chronic denervation. ${ }^{(8)}$

NCS provide information regarding the presence, severity and location of a peripheral neuropathy, mononeuropathy or disorders affecting the neuromuscular junctions. Also the functional modality most involved (sensory or motor) and the predominant pattern of pathology (e.g., axonal, demyelinating, or both). ${ }^{(8) 9}$ In NCS surface electrodes are usually used for both stimulation and recording of the electrical responses. However; needle electrodes are sometimes needed to evaluate a deep nerve, such as the sciatic or the femoral nerve. ${ }^{(8,9)}$

\section{The aim of the study}

- To study the nerve conduction and electromyography in normal subjects.

- To evaluate the nerve and muscle involvement in rheumatoid arthritis patients through the nerve conduction study and electromyography. 
- To estimate of RF, ESR, CRP and CPK in RA patients.

\section{SUBJECTS AND METHODS}

The study has been conducted at the Rheumatology and Neurophysiology Department in Ibn- Sina Teaching Hospital, in Mosul, during the period from $15^{\text {th }}$ of November 2009 to $15^{\text {th }}$ of May 2010. One hundred RA patients whose ages are above 20 years were included; diagnosis was made according to American revised criteria (ARC) $1987 . .^{(12)}$

One hundred normal subjects of healthy volunteers of similar age and sex, were compared to rheumatoid arthritis patients, and were examined for nerve conduction, and electromyography.

NCS for median, ulnar, radial (motor and sensory), posterior tibial and common peroneal nerves were done for each patient and normal subject to study the distal motor and sensory latency (DML, DSL), compound motor and sensory action potentials (CMAP, SNAP), and motor and sensory nerve conduction velocities (MNCV, SNCV) by using the system 98- MyoQuik (micromed) EMG machine.

Electromyography for gastrocnemius, tibialis anterior and quadriceps muscles for RA patients and normal subjects were done by using DANTEC Neuromatic 2000 M. to study the: insertional activity, spontaneous activity, motor unit potential and recruitments.

Collected data were analysed by (SPSS) software; unpaired t-test was used to compare between the studied parameters. P-value equal to or less than 0.05 is considered to be significant.

\section{RESULTS}

Are shown in figure 1-3 and tables 1-8.

Figure 1 shows the nerve conduction study for median nerve for normal subjects and RA patients; there is increase in distal latency, decrease in compound motor action potential and decrease in nerve conduction velocity for RA patients compared to normal subjects and these differences are significant.

Figure 2 shows the nerve conduction study for for ulnar nerve for normal subjects and RA patients; there is increase in distal latency, decrease in compound motor action potential and decrease in nerve conduction velocity for RA patients compared to normal subjects and these differences are significant.

Figure 3 shows the nerve conduction study for posterior-tibial nerve for normal subjects and RA patients; there is increase in distal latency, decrease in compound motor action potential and decrease in nerve conduction velocity for RA patients compared to normal subjects and these differences are significant.

Table 1 shows prolonged distal latency for rheumatoid arthritis patients than that of normal subjects with significant difference between them ( $P=0.01$ ), except for the radial nerve it is not significant.

Table 2 shows a decrease of the compound motor action potentials (CMAP) for rheumatoid arthritis patients compared to normal subjects with significant difference between them ( $P \leq 0.05)$; except for radial nerve which is not significant.

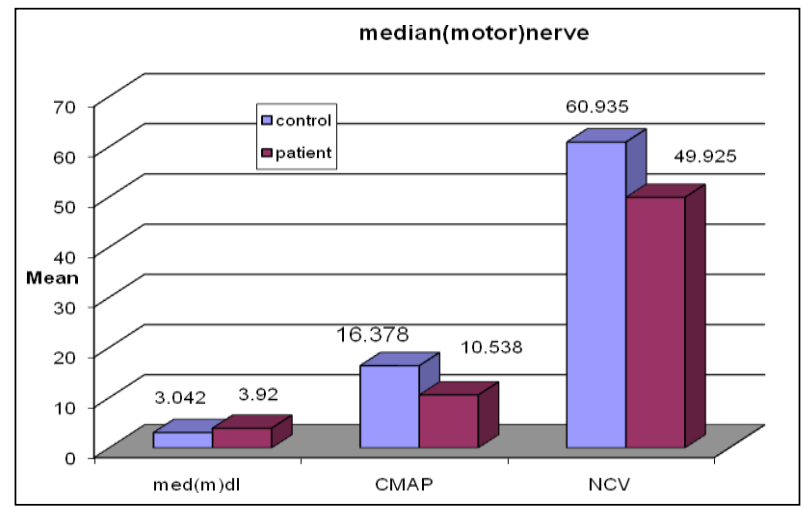

(dl: distal latency (ms), CMAP: compound action potential (mv), NCV: nerve conduction velocity $(\mathrm{m} / \mathrm{s})$ ).

Figure 1. Median (motor) nerve conduction study for normal subjects and rheumatoid arthritis patients.

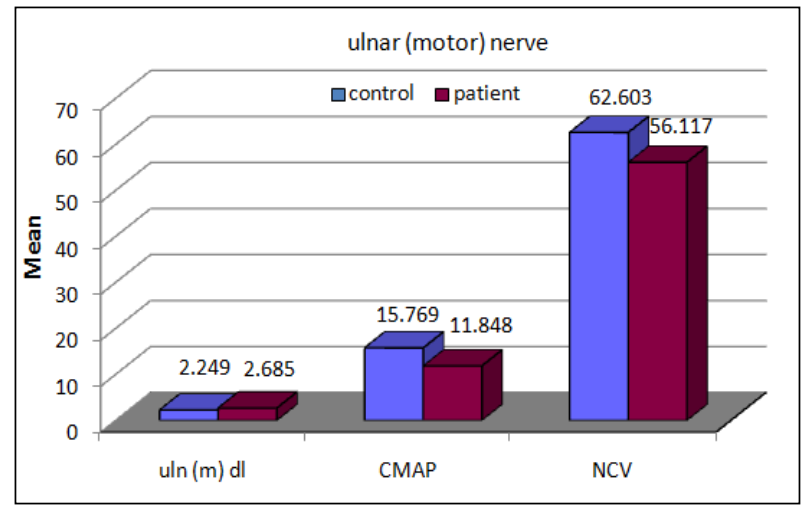

(dl: distal latency (ms), CMAP: compound action potential (mv), NCV: nerve conduction velocity $(\mathrm{m} / \mathrm{s})$ ).

Figure 2. Ulnar (motor) nerve conduction study for normal subjects and rheumatoid arthritis patients. 


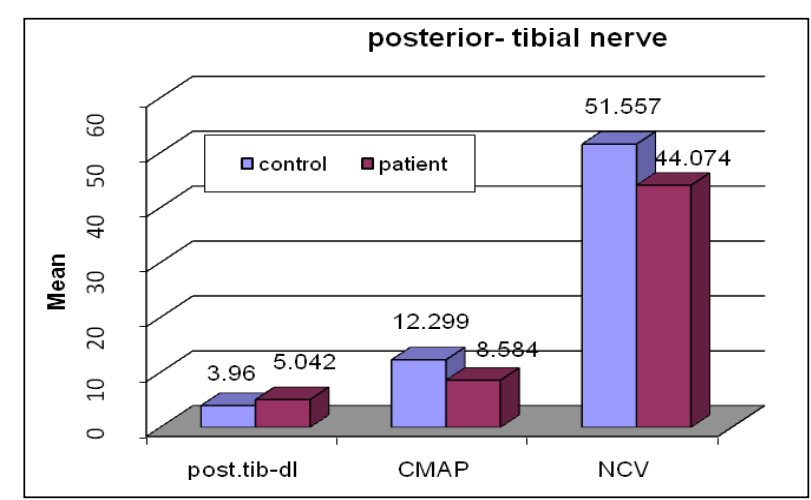

(dl: distal latency (ms), CMAP: compound action potential (mv), NCV: nerve conduction velocity $(\mathrm{m} / \mathrm{s})$ ).

Figure 3. Posterior tibial nerve conduction study for normal subjects and rheumatoid arthritis patients.

Table 3 shows that the motor nerve conduction velocities (MNCV) for patients were less than that of normal subjects with significant difference between them $(P<0.05)$, while for the radial nerve it is not significant.
Table 4 shows prolongation of sensory distal latency (SDL) for rheumatoid arthritis patients compared to normal subjects with significant difference between them $(P=0.01)$.

The sensory nerve action potential (SNAP) was less in rheumatoid arthritis patients than in normal subjects with significant difference between them $(P<0.01)$ except for radial nerve which is not significant, as shown in Table 5. Table 6 shows that the sensory nerve conduction velocities (SNCV) were less for rheumatoid arthritis patients than normal subjects with significant difference between them $(P<0.05)$, except in radial nerve not significant.

Table 7 shows the type of peripheral neuropathy in RA patients, there are mononeuritis simplex detected in 36 patients (66.66\%); mononeuritis multiplex detected in 11 patients (20.37\%) and symmetrical poly neuropathy detected in seven patients (12.90\%).

Table 1. Distal motor latency (DML) of median, ulnar, radial, common peroneal and posterior tibial nerve in normal subjects and rheumatoid arthritis patients.

\begin{tabular}{|c|c|c|c|c|}
\hline Nerve & \multicolumn{2}{|c|}{ Normal subjects (No.=100) } & $\begin{array}{l}\text { Rheumatoid arthritis } \\
\text { patients (No.=100) }\end{array}$ & $P$-value \\
\hline $\begin{array}{l}\text { Median nerve } \\
\mathrm{DML}(\mathrm{ms})\end{array}$ & $\begin{array}{l}\text { Mean } \pm S D \\
\text { Range }\end{array}$ & $\begin{aligned} 3.042 & \pm 0.315 \\
2.30 & -3.60\end{aligned}$ & $\begin{aligned} 3.920 & \pm 0.742 \\
2.60 & -6.20\end{aligned}$ & $0.01^{* *}$ \\
\hline $\begin{array}{l}\text { Ulnar nerve } \\
\text { DML (ms) }\end{array}$ & $\begin{array}{c}\text { Mean } \pm S D \\
\text { Range }\end{array}$ & $\begin{array}{c}2.249 \pm 0.364 \\
1.70-3.00\end{array}$ & $\begin{aligned} 2.685 & \pm 0.529 \\
2.00 & -4.70\end{aligned}$ & $0.01^{* *}$ \\
\hline $\begin{array}{l}\text { Radial nerve } \\
\mathrm{DML}(\mathrm{ms})\end{array}$ & $\begin{array}{l}\text { Mean } \pm S D \\
\text { Range }\end{array}$ & $\begin{array}{c}3.023 \pm 0.250 \\
1.80-3.500\end{array}$ & $\begin{aligned} 3.281 & \pm 0.363 \\
2.50 & -3.75\end{aligned}$ & (NS) \\
\hline $\begin{array}{l}\text { Common peroneal nerve } \\
\text { DML }(\mathrm{ms})\end{array}$ & $\begin{array}{l}\text { Mean } \pm S D \\
\text { Range }\end{array}$ & $\begin{array}{c}3.859 \pm 0.224 \\
3.20-4.50\end{array}$ & $\begin{array}{c}4.534 \pm 0.645 \\
2.80-6.70\end{array}$ & $0.01^{* *}$ \\
\hline Posterior tibial nerve DML(ms) & $\begin{array}{l}\text { Mean } \pm S D \\
\text { Range }\end{array}$ & $\begin{aligned} 3.690 & \pm 0.249 \\
3.30 & -4.60\end{aligned}$ & $\begin{aligned} 5.042 & \pm 0.983 \\
3.40 & -8.00\end{aligned}$ & $0.01^{* *}$ \\
\hline
\end{tabular}

${ }^{* *}$ Highly significant $(P<0.01)$, (NS) not significant.

Table 2. Compound motor action potential (CMAP) of median, ulnar, radial, common peroneal and posterior tibial nerve of normal subjects and rheumatoid arthritis patients.

\begin{tabular}{|c|c|c|c|c|}
\hline Nerve & Nor & $\begin{array}{l}\text { ubjects } \\
00)\end{array}$ & $\begin{array}{l}\text { Rheumatoid arthritis } \\
\text { patients (No.=100) }\end{array}$ & $P$-value \\
\hline $\begin{array}{l}\text { Median nerve } \\
\text { CMAP (mv) }\end{array}$ & $\begin{array}{l}\text { Mean } \pm S D \\
\text { Range }\end{array}$ & $\begin{array}{c}16.378 \pm 2.721 \\
8.00-19.90\end{array}$ & $\begin{array}{c}10.530 \pm 3.630 \\
3.30-19.30\end{array}$ & 0.04 * \\
\hline $\begin{array}{l}\text { Ulnar nerve } \\
\text { CMAP (mv) }\end{array}$ & $\begin{array}{l}\text { Mean } \pm S D \\
\text { Range }\end{array}$ & $\begin{array}{c}15.769 \pm 3.208 \\
8.00-20.00 \\
\end{array}$ & $\begin{array}{c}11.840 \pm 3.580 \\
5.50-20.00\end{array}$ & 0.02 * \\
\hline $\begin{array}{l}\text { Radial nerve } \\
\text { CMAP (mv) }\end{array}$ & $\begin{array}{l}\text { Mean } \pm S D \\
\text { Range }\end{array}$ & $\begin{array}{c}15.376 \pm 2.621 \\
9.00-19.00\end{array}$ & $\begin{array}{c}12.340 \pm 2.855 \\
7.00-19.00\end{array}$ & (NS) \\
\hline $\begin{array}{l}\text { Common peroneal nerve } \\
\mathrm{CMAP}(\mathrm{mv})\end{array}$ & $\begin{array}{l}\text { Mean } \pm S D \\
\text { Range }\end{array}$ & $\begin{array}{c}11.927 \pm 2.881 \\
8.00-19.30\end{array}$ & $\begin{array}{c}8.368 \pm 2.166 \\
3.90-17.00\end{array}$ & $0.05^{\star}$ \\
\hline $\begin{array}{l}\text { Posterior tibial nerve } \\
\text { CMAP (mv) }\end{array}$ & $\begin{array}{l}\text { Mean } \pm S D \\
\text { Range }\end{array}$ & $\begin{array}{c}12.290 \pm 2.360 \\
7.00-19.00\end{array}$ & $\begin{array}{c}8.594 \pm 2.721 \\
3.00-18.00\end{array}$ & 0.04 * \\
\hline
\end{tabular}

*Significant (PS0.05), (NS) not significant. 
Table 8 shows nerve entrapment, which was detected in 25 patients $(46.28 \%$ ) (out of 36 patients who developed mononeuritis simplex) affecting mainly the median $(24.07 \%)$, ulnar $(7.40 \%)$ and posterior tibial (14.81\%) nerve.

The electromyography which includes the spontaneous activity (fibrillation potential and $\backslash$ or positive sharp waves-FP, PSW), the motor unit potential (MUP) which include (Duration, Amplitute and number of phases) and interference (recruitment) of tibialis anterior, gasrtrocnemius and quadriceps muscles for normal subjects and rheumatoid arthritis patients shows differences between them which were not significant.

The normal subjects in this study showed neither nerve conduction study for median, ulnar and radial nerves (motor and sensory) abnormalities, nor needle muscle study for tibialis anterior, and gastrocnemius muscles abnormalities.

Table 3. Motor nerve conduction velocity (MNCV) of median, ulnar, radial, common peroneal and posterior tibial nerves of normal subjects and rheumatoid arthritis patients.

\begin{tabular}{|c|c|c|c|c|}
\hline Nerve & & $\begin{array}{l}\text { ubjects } \\
00)\end{array}$ & $\begin{array}{c}\text { Rheumatoid arthritis } \\
\text { patients (No.=100) }\end{array}$ & P- value \\
\hline $\begin{array}{l}\text { Median nerve } \\
\mathrm{NCV}(\mathrm{m} / \mathrm{s})\end{array}$ & $\begin{array}{l}\text { Mean } \pm S D \\
\text { Range }\end{array}$ & $\begin{array}{l}60.93 \pm 3.89 \\
50.00-78.00\end{array}$ & $\begin{array}{l}49.92 \pm 8.55 \\
35.00-76.00\end{array}$ & $0.01^{* *}$ \\
\hline $\begin{array}{l}\text { Ulnar nerve } \\
\mathrm{NCV}(\mathrm{m} \backslash \mathrm{s})\end{array}$ & $\begin{array}{l}\text { Mean } \pm S D \\
\text { Range }\end{array}$ & $\begin{array}{l}62.60 \pm 5.13 \\
51.00-77.00\end{array}$ & $\begin{array}{l}56.11 \pm 4.84 \\
40.00-70.00\end{array}$ & $0.02^{*}$ \\
\hline $\begin{array}{l}\text { Radial nerve } \\
\mathrm{NCV}(\mathrm{m} \backslash \mathrm{s})\end{array}$ & $\begin{array}{l}\text { Mean } \pm S D \\
\text { Range }\end{array}$ & $\begin{array}{l}58.41 \pm 3.37 \\
50.00-70.00\end{array}$ & $\begin{array}{l}53.78 \pm 3.59 \\
45.00-60.00\end{array}$ & (NS) \\
\hline $\begin{array}{l}\text { Common peroneal nerve } \\
\operatorname{NCV}(m \backslash s)\end{array}$ & $\begin{array}{l}\text { Mean } \pm S D \\
\text { Range }\end{array}$ & $\begin{array}{l}52.09 \pm 2.70 \\
45.00-59.00\end{array}$ & $\begin{array}{l}46.94 \pm 4.13 \\
30.50-56.40\end{array}$ & $0.01 * *$ \\
\hline $\begin{array}{l}\text { Posterior tibial nerve } \\
\mathrm{NCV}(\mathrm{m} / \mathrm{s})\end{array}$ & $\begin{array}{l}\text { Mean } \pm S D \\
\text { Range }\end{array}$ & $\begin{array}{l}51.55 \pm 3.37 \\
40.00-55.00\end{array}$ & $\begin{array}{l}44.07 \pm 6.38 \\
38.00-55.70\end{array}$ & $0.01^{* *}$ \\
\hline
\end{tabular}

${ }^{*}$ Significant $(P<0.05),{ }^{* *}$ highly significant $(P<0.01)$, (NS) not significant.

Table 4. Sensory distal latency (SDL) of median, ulnar and radial nerves for normal subjects and rheumatoid arthritis patients.

\begin{tabular}{|c|c|c|c|c|}
\hline Nerve & Nor & $\begin{array}{l}\text { Subjects } \\
=100)\end{array}$ & $\begin{array}{c}\text { Rheumatoid arthritis } \\
\text { patient }(\text { No. }=100)\end{array}$ & $P$-value \\
\hline $\begin{array}{l}\text { Median nerve } \\
\text { SDL }(\mathrm{ms})\end{array}$ & $\begin{array}{l}\text { Mean } \pm \text { SD } \\
\text { Range }\end{array}$ & $\begin{aligned} 2.367 & \pm 0.217 \\
2.04 & -2.90\end{aligned}$ & $\begin{array}{c}3.393 \pm 1.044 \\
2.50-5.40\end{array}$ & $0.01^{* *}$ \\
\hline $\begin{array}{l}\text { Ulnar nerve } \\
\text { SDL (ms) }\end{array}$ & $\begin{array}{l}\text { Mean } \pm S D \\
\text { Range }\end{array}$ & $\begin{array}{c}2.070 \pm 0.154 \\
1.95-2.70\end{array}$ & $\begin{aligned} 2.939 & \pm 0.507 \\
1.80 & -4.90\end{aligned}$ & $0.01^{* *}$ \\
\hline $\begin{array}{l}\text { Radial nerve } \\
\text { SDL (ms) }\end{array}$ & $\begin{array}{l}\text { Mean } \pm S D \\
\text { Range }\end{array}$ & $\begin{array}{c}2.098 \pm 0.1626 \\
1.50-3.00\end{array}$ & $\begin{aligned} 2.981 & \pm 0.262 \\
2.00 & -3.40\end{aligned}$ & $0.01^{* *}$ \\
\hline
\end{tabular}

${ }^{* *}$ Highly significant $(P<0.01)$.

Table 5. Sensory nerve action potentials (SNAP) of median, ulnar and radial nerves for normal subjects and rheumatoid arthritis patients.

\begin{tabular}{|c|c|c|c|c|}
\hline Nerve & & $\begin{array}{l}\text { subject } \\
100\end{array}$ & $\begin{array}{c}\text { Rheumatoid arthritis } \\
\text { patient }(\text { No. }=100)\end{array}$ & P -value \\
\hline $\begin{array}{l}\text { Median nerve } \\
\text { SNAP }(\mathrm{mv})\end{array}$ & $\begin{array}{l}\text { Mean } \pm S D \\
\text { Range }\end{array}$ & $\begin{array}{c}32.777 \pm 7.492 \\
14.50-49.00\end{array}$ & $\begin{array}{c}23.220 \pm 9.649 \\
10.00-48.00\end{array}$ & $0.01^{\star *}$ \\
\hline $\begin{array}{l}\text { Ulnar nerve } \\
\text { SNAP }(\mathrm{mv})\end{array}$ & $\begin{array}{l}\text { Mean } \pm S D \\
\text { Range }\end{array}$ & $\begin{array}{c}32.515 \pm 6.819 \\
15.00-46.00\end{array}$ & $\begin{array}{c}27.090 \pm 8.132 \\
8.50-45.00\end{array}$ & $0.01^{* *}$ \\
\hline $\begin{array}{l}\text { Radial nerve } \\
\text { SNAP (mv) }\end{array}$ & $\begin{array}{l}\text { Mean } \pm S D \\
\text { Range }\end{array}$ & $\begin{array}{c}31.640 \pm 6.999 \\
13.00-43.96\end{array}$ & $\begin{aligned} 28.627 & \pm 6.713 \\
14.00 & -40.00\end{aligned}$ & (NS) \\
\hline
\end{tabular}

**Highly Significant $(P<0.01)$, (NS) not significant. 
Table 6. Sensory nerve conduction velocity (SNCV) of median, ulnar and radial nerves for normal subjects and rheumatoid arthritis patients.

\begin{tabular}{|c|c|c|c|c|}
\hline Nerve & & $\begin{array}{l}\text { ubjects } \\
\text { 100) }\end{array}$ & $\begin{array}{l}\text { Rheumatoid arthritis } \\
\text { patients }(\text { No. }=100)\end{array}$ & P- value \\
\hline $\begin{array}{l}\text { Median nerve } \\
\text { SNCV (mls) }\end{array}$ & $\begin{array}{l}\text { Mean } \pm S D \\
\text { Range }\end{array}$ & $\begin{array}{l}60.913 \pm 4.940 \\
50.00-80.00\end{array}$ & $\begin{array}{l}50.272 \pm 7.860 \\
38.00-67.00\end{array}$ & $0.01^{* *}$ \\
\hline $\begin{array}{l}\text { Ulnar nerve } \\
\text { SNCV (mls) }\end{array}$ & $\begin{array}{l}\text { Mean } \pm S D \\
\text { Range }\end{array}$ & $\begin{array}{l}60.572 \pm 5.228 \\
48.00-77.00\end{array}$ & $\begin{array}{l}54.182 \pm 5.561 \\
35.00-65.60\end{array}$ & $0.04^{*}$ \\
\hline $\begin{array}{l}\text { Radial nerve } \\
\text { SNCV (mls) }\end{array}$ & $\begin{array}{l}\text { Mean } \pm S D \\
\text { Range }\end{array}$ & $\begin{array}{l}59.537 \pm 3.604 \\
50.00-69.50\end{array}$ & $\begin{array}{l}56.387 \pm 4.137 \\
50.00-65.00\end{array}$ & (NS) \\
\hline
\end{tabular}

*Significant $(P<0.05)$, ${ }^{* *}$ Highly Significant $(P<0.01)$, (NS) not significant.

Table 7. Type of peripheral neuropathy findings in rheumatoid arthritis patients.

\begin{tabular}{|l|c|}
\hline \multicolumn{1}{|c|}{ Type } & $\begin{array}{c}\text { Positive peripheral } \\
\text { neuropathy 54 } \\
\text { patients (54\%) }\end{array}$ \\
\hline Mononeuritis simplex & $36 \mathrm{Pt}(66.66 \%)$ \\
\hline Mononeuritis multiplex & $11 \mathrm{Pt} .(20.37 \%)$ \\
\hline Symmetrical polyneuropathy & $7 \mathrm{Pt}$ (12.90\%) \\
\hline
\end{tabular}

Table 8. Type, severity and site of nerve entrapment in rheumatoid arthritis patients.

\begin{tabular}{|c|c|c|}
\hline Nerve & $\begin{array}{l}\text { Type, severity } \\
\text { and site }\end{array}$ & $\begin{array}{c}\text { Nerve } \\
\text { entrapment } \\
\text { No=25pt. } \\
(46.28 \%)\end{array}$ \\
\hline $\begin{array}{l}\text { Median nerve } \\
\text { entrapment } \\
13 \text { pt. }(24.07 \%)\end{array}$ & $\begin{array}{c}\text { Mild } \\
\text { Moderat } \\
\text { Severe }\end{array}$ & $\begin{array}{c}6 \text { pt. }(11.11 \%) \\
7 \text { pt. }(12.96 \%) \\
0.00(0.00 \%)\end{array}$ \\
\hline $\begin{array}{l}\text { Ulnar nerve } \\
\text { entrapment } \\
4 \text { pt. }(7.40 \%)\end{array}$ & $\begin{array}{l}\text { At Cubital -fossa } \\
\text { At Guyon canal }\end{array}$ & $\begin{array}{l}2 \text { pt. }(3.70 \%) \\
2 \text { pt. }(3.70 \%)\end{array}$ \\
\hline $\begin{array}{l}\text { Posterior tibial nerve } \\
\text { entrapment } \\
8 \text { pt. }(14.81 \%)\end{array}$ & $\begin{array}{l}\text { Medial Planter } \\
\text { Lateral planter }\end{array}$ & $\begin{array}{l}\text { 5pt. }(9.25 \%) \\
3 \text { pt. }(5.55 \%)\end{array}$ \\
\hline
\end{tabular}

\section{DISCUSSION}

This study demonstrates the involvement of peripheral nerves in rheumatoid arthritis patients, which is a common feature and one of the common complications of the disease.

There were many changes in parameters of the nerves study regarding the distal latency, compound motor action potential and nerve conduction study in rheumatoid arthritis patients and normal subjects; these represent the preliminary changes of neuropathic lesions in RA patients.

The explanation for the differences in these measures was that; in rheumatoid arthritis there is nerve compression (nerve entrapment) which causes mechanical (direct) pressure that affects mainly the myeline sheath of these nerves (at the begining); so this will lead to a prolonged MDL and SDL and a decrease in MNCV and SNCV, with normal or slight decreases of CMAP and SNAP, which were detected by nerve conduction study. Later on, if this pressure persists, it will affect the axon leading to the decrease of the CMAP and SNAP. These findings may represent the preliminary picture of any peripheral neuropathy pattern. ${ }^{(13,14)}$ Other causes are vasculitic lesions in rheumatoid arthritis which cause ischemic changes that affect the axon mainly and lead to axonopathy that causes the decrease of the CMAP and SNAP; and hence it was detected by nerve conduction study ${ }^{(15,16)}$.

In the present study, the peripheral neuropathy findings in RA patients were detected in 54 patients (54\%) and these findings are in agreement with other studies. ${ }^{(17,18)}$ This may be due to geographical similarity. Another cause is vasculopathy; vascular injury is considered as a key finding in the pathogenesis of rheumatoid arthritis. It is responsible for the different patterns of non-compressive peripheral neuropathy in RA including mononeuritis multiplex and distal symmetrical sensory or sensorimotor neuropathy. ${ }^{(19,20)}$

In this study, mononeuritis simplex was detected in 36 patients $(66.6 \%)$ out of 54 patients who developed peripheral neuropathy and this is in agreement with another study ${ }^{(21)}$ (Table 7). Entrapment neuropathy was found in 25 patients $(46.28 \%$ ) (out of the 36 patients with mononeuritis simplex). The entrapment neuropathy affects mainly the median, ulnar and posterior tibial nerve (Table 8).

The carpal tunnel syndrome (CTS) of median nerve at the wrist is the most common form of median nerve entrapment and is the prototypical injury. ${ }^{(22)}$ In present study CTS was detected in 13 
patients $(24.07 \%)$ and this was similar to other studies. $^{(21,23)}$ Mild carpal tunnel syndrome was detected in 6 patients $(11.11 \%)$, moderate carpal tunnel in 7 patients (12.96\%), and none of the patients showed severe degree of carpal tunnel syndrome in this study.

The second common type of nerve entrapment in our study was tarsal tunnel syndrome of posterior tibial nerve, which was detected in 8 patients $(14.81 \%)$ and this is nearly in agreement with another study. ${ }^{(24)}$ The medial planter nerve involved in 5 patients $(9.25 \%)$, while the lateral planter nerve involved in 3 patients $(5.55 \%)$.

The third common nerve entrapment in rheumatoid arthritis patients in this study was ulnar nerve entrapment which was detected in 4 patients $(7.40 \%)$ and this was nearly similar to findings of another study; ${ }^{(17)}$ the ulnar nerve entrapment at the cubital area was detected in 2 patients $(3.70 \%)$ and at the Guyon canal by 2 patients $(3.70 \%)$ also.

Mononeuritis multiplex was detected in 11 patients $(20.37 \%)$ and this is nearly in agreement with the findings in another study. ${ }^{(25)}$ Symmetrical polyneuropathy was seen in 7 patients (12.9\%) and this finding was similar to the findings of another study. ${ }^{(17)}$

The needle muscle study of tibialis anterior, gastrocnemius and quadriceps muscles for normal subjects and rheumatoid arthritis patients show that there were no significant differences between them in this study. This finding was in agreement with another study, which found that there were neurogenic changes in rheumatoid arthritis patients but no myogenic changes. ${ }^{(26)}$

\section{CONCLUSION}

Neurogenic lesions were present, while no myogenic lesion was detected in patients with rheumatoid arthritis.

\section{REFERENCES}

1. Kar M, Mukherjee S, Mandal D, et al. Neuropathy in rheumatoid arthritis: clinical and electrophysiological observations. Bull Indian Rheumatism Assoc 1991; 5: 80-2.

2. Kim RC, Collins GH, Parisi JE. Rheumatoid nodule formation within the choroid plexus. Report of a second case. Arch Pathol Lab Med 1982; 106:83.

3. McCombe PA. "Sensorimotor peripheral neuropathy in rheumatoid arthritis", Clin Exp Neurol 1991; 28: 146-53.
4. Puechal X, Said G, Hilliquin $P$, et al. Peripheral neuropathy with necrotizing vasculitis in rheumatoid arthritis: a clinicopathologic and prognostic study of thirty-two patients. Arthritis Rheum 1995; 38(11): 1618- 1629.

5. Ekdahl C, Broman G. Muscle strength, endurance, and aerobic capacity in rheumatoid arthritis: a comparative study with healthy subjects. Ann Rheum Dis 1992;51(1):35 - 40

6. Helliwell P S, Jackson S. Relationship between weakness and muscle wasting in rheumatoid arthritis. Ann Rheum Dis 1994;53:726-728.

7. American Association of Neuromuscular and Electrodiagnostic Medicine (AANEM, formerly AAEN). Recommended Policy for Electrodiagnostic Medicine. Rochester, MN. September 1997, updated 2004.

8. Bolton C, Walker FO. Electromyography and nerve conduction study (EMG/NCS). Sensory nerve conduction study workshop. American Academy of Neurology, Annual Meeting, Workshop Washington DC: May 2, 1994. p. 250.

9. England JD, Gronseth GS, Franklin G, et al. Distal symmetric polyneuropathy: A definition for clinical research. Report of the American Academy of Neurology, the American Association of Neuromuscular and Electrodiagnostic Medicine (AAEN) and the American Academy of Physical Medicine and Rehabilitation. Neurology 2005; 64: 199-207.

10. Hilburn JW. General principles and use of electrodiagnostic studies in carpal and cubital tunnel syndrome. With special attention to pitfalls and interpretation. Hand Clin. 1996; 12(2): 205-221.

11. Wilbourn AJ, Aminoff MJ. AAEE Minimonograph: The electrophysiologic examination in patients with radiculopathies. Muscle Nerve. 1998; 21(12):16211631.

12. Arnett FC, Edworthy SM, Bloch DA, et al. The American Rheumatism Association 1987; revised criteria for the classification of rheumatoid arthritis. Arthritis Rheum 1988;31(3):315-324.

13. Aktekin L, Gözlükaya H, Bodur H. Peripheral Neuropathy in Rheumatoid Arthritis Patients; An Electroneuro physiological Study; Turk J Rheumatol 2009; 24:62-64.

14. Aminof MJ, editor. Electrodiagnosis in clinical neurology. In Nerve conduction studies, $3^{\text {rd }}$ edition, New York: Churchill Livingstone 1992.p. 260-275.

15. Raynor E, Preston D. Electrophysiology: Nerve conduction studies and electromyography: living Martin A. $4^{\text {th }}$ edition. Samnels Fesk: Office practice of neurology: Churchill living stone Inc. 2002. p.168177.

16. Aminof MJ, editor. Electrodiagnosis in clinical neurology. In Nerve conduction studies. $4^{\text {rd }}$ edition. 
New York: Edinburgh, Philadelphia, San Francisco 1999. p.275-286.

17. Yazdchi M, Ebrahimi A, Mikaeeli $H$. The Electrophysiological Evaluation of 70 Iranian Rheumatoid Arthritis Patients; Journal of Neurological Sciences (Turkish) 2007: 24(3)190195.

18. Vikas A, Wiclaf S, Sandeep C. A clinical, electrophysiological, and pathological study of neuropathy in rheumatoid arthritis; Clinical rheumatology 2008; 27: 841-844.

19. Muramatsu K, Tanaka H, Taguchi: T. Peripheral neuropathies of the forearm and hand in rheumatoid arthritis: diagnosis and options for treatment; $J$ Rheumatology international 2008; 28(10):951- 957.

20. Yasser M, Miedany E, Ashour S, et al. Altered Levels of Soluble Adhesion Molecules in Patients with Rheumatoid Arthritis Complicated by Peripheral Neuropathy. J Rheumatology 2002; 29: 57-61.

21. Sakini R, Abdul-Zehra I, Al-Nimer M. Neuropathic manifestations in rheumatoid arthritis: a clinical and electrophysiological assessment in a small sample of Iraqi patients; Ann Saudi Med. 2005;25 (3): 247249.
22. Lanzillo B, Pappone N, Crisci C, et al. Subclinical peripheral nerve involvement in patients with rheumatoid arthritis; Arthritis and rheumatism 2004; 41(7): $1196-1202$.

23. Aluclu M, Turhanoglu A. The Frequency Of Carpal Tunnel Syndrome In Patients With Rheumatoid Arthritis. Journal of Neurology 2006;5(2): 66-71.

24. McGuigan L, Burke D, Fleming A. Tarsal tunnel syndrome and peripheral neuropathy in rheumatoid disease; Ann Rheum Dis. 1981; 42(2):128-131.

25. Sivir A, Güler F. The electroneurophysiological evaluation of Rheumatoid Arthritis patients; Clinical Rheumatology 2005;17(5): 416-418.

26. Bekklund SI, Torbergsen S I, Husby G. Myopathy and neuropathy in rheumatoid arthritis. a quantitative controlled electromyographic study Journal of rheumatolog, 1999; 26 (11): 2348-2351. 